\title{
Government ownership and performance: an analysis of listed companies in Malaysia
}

\begin{abstract}
The relationship between ownership structure and company performance has been issue of interest among academics, investors and policy makers because of key issue in understanding the effectiveness of alternative governance system in which government ownership serve as a control mechanism. Therefore, this paper examines the impact of an alternative ownership/control structure of corporate governance on firm performance among government linked companied (GLCs) and Non-GLC in Malaysia. It is believed that government ownership serve as a monitoring device that lead to better company performance after controlling company specific characteristics. We used Tobinôs $\mathrm{Q}$ as market performance measure while ROA is to determine accounting performance measure. This study is based on a sample of 210 firms over a period from 1995 to 2005 . We use panel based regression approach to determine the impact of ownership mechanism on firmôs performance. Findings appear to suggest that there is a significant impact of government ownership on company performance after controlling for company specific characteristics such as company size, non-duality, leverage and growth. The finding is off significant for investors and policy marker which will serve as a guiding for better investment decision.
\end{abstract}

Keyword: Government ownership; Government linked companies; Corporate governance 